\title{
EVALUASI PERTUMBUHAN DAN PERKEMBANGAN GONAD IKAN SERUKAN Osteochilus sp YANG DIBERI PAKAN TEPUNG KUNYIT
}

\section{EVALUATION OF GROWTH AND GONAD DEVELOPMENT OF SERUKAN FISH Osteochilus sp THAT GIVEN TURMERIC FLOUR FEED}

\author{
Yusran Ibrahim ${ }^{\text {*) }}$, Fazril Saputra ${ }^{1)}$, Devi Yusnita ${ }^{2)}$, Abdul Karim²) \\ ${ }^{1}$ Jurusan Akuakultur, Fakultas Perikanan dan Ilmu Kelautan, Universitas Teuku Umar \\ ${ }^{2}$ Jurusan Perikanan, Fakultas Perikanan dan Ilmu Kelautan, Universitas Teuku Umar \\ *Korespondensi: yusranibrahim@utu.ac.id
}

\begin{abstract}
ABSTRAK
Penelitian ini bertujuan untuk mengevaluasi pertumbuhan dan perkembangan gonad ikan serukan yang diberikan pakan tepung kunyit. Metode penelitian eksperimental menggunakan Rancangan Acak Lengkap (RAL) dengan 4 perlakuan dan 3 ulangan. Empat dosis tepung kunyit dicampur ke dalam pakan yaitu $0,0,2,0,4$, dan $0,6 \% / \mathrm{kg}$. Induk yang digunakan dalam percobaan adalah induk betina ikan serukan sebanyak 120 ekor (10 ekor/wadah) berukuran panjang 12-14 cm dan bobot 30$40 \mathrm{~g}$ hasil tangkapan dan penangkaran kelompok petani ikan di Kabupaten Nagan Raya. Parameter yang diamati yaitu pertumbuhan (bobot dan panjang), gonadosomatic index (GSI) dan hepatosomatic index (HSI). Hasil penelitian menunjukkan bahwa pemberian tepung kunyit dapat meningkatkan pertumbuhan dan mempercepat proses perkembangan gonad ikan dengan dosis terbaik yaitu $\mathrm{P} 4(0,6 \% / \mathrm{kg}$ pakan).
\end{abstract}

Kata kunci: pertumbuhan, gonadosomatic index, hepatosomatic index, Osteochilus sp.

\begin{abstract}
This study aims to evaluate the growth and gonads development of serukan fish that are given the feed of turmeric flour. Experimental research method using Completely Randomized Design (CRD) with 4 treatments and 3 replications. Four doses of turmeric flour were mixed into feed, namely $0,0.2,0.4$, and $0.6 \% / \mathrm{kg}$. The fish used in the experiment were 120 individuals $(10$ individus/net), length of fish is $12-14 \mathrm{~cm}$ and weight $30-40 \mathrm{~g}$ of caught and breeding of fish farmer groups in Nagan Raya District. Parameters observed were growth (weight and length), gonadosomatic index (GSI) and hepatosomatic index (HSI). The results showed that giving turmeric flour can increase growth and improve gonadal development of Serukan fish with the best dose, $\mathrm{P} 4(0.6 \%$ / kg feed).
\end{abstract}

Keywords: growth, gonadosomatic index, hepatosomatic index, Osteochilus sp.

\footnotetext{
${ }^{1}$ Fakultas Perikanan dan Ilmu Kelautan, Universitas Teuku Umar Korespondensi: Jurusan Akuakultur, Fakultas Perikanan dan Ilmu Kelautan, Universitas Teuku Umar, Kampus UTU Meulaboh, Alue Peunyareng 23615, Telp: +62 8116800980, email: yusranibrahim@utu.ac.id
} 


\section{PENDAHULUAN}

Ikan serukan Osteochilus sp. merupakan salah satu komoditas lokal Indonesia yang memiliki nilai ekonomis tinggi, harga di pasar berkisar antara Rp 30.000-35.000 per kg dan merupakan kandidat potensial untuk spesies akuakultur. Syandri et al. (2015) menyatakan bahwa selain untuk konsumsi, ikan $O$. vittatus juga dapat berperan sebagai biokontrol dalam mengurangi blooming fitoplankton di perairan. Ikan serukan tersebar di perairan Pulau Sumatera dan Jawa, khusus di Aceh ikan ini banyak terdapat di wilayah Kabupaten Nagan Raya dan Aceh Selatan (Muchlisin dan Azizah 2009).

Teknologi budidaya ikan serukan belum berkembang dengan baik, saat ini masyarakat umumnya masih mengandalkan benih dari alam karena tingkat keberhasilan pembenihannya masih rendah. Kajian reproduksi sangat memengaruhi upaya pembenihan, namun informasi tentang perkembangan gonad hingga performa reproduksi ikan serukan masih sangat sedikit.

Kualitas pakan merupakan faktor penting yang dapat memengaruhi perkembangan gonad ikan, performa reproduksi, fekunditas, daya tetas dan kelangsungan hidup. Dalam budidaya ikan, pakan merupakan komponen utama untuk proses pembentukan vitelogenin (bakal kuning telur), penambahan nutrien tertentu dalam pakan dapat mempercepat proses pematangan dan memperbaiki kualitas gonad. Kunyit Curcuma longa merupakan salah satu tanaman herbal yang mampu memberikan banyak manfaat untuk meningkatkan produktivitas makhluk hidup. Kunyit mengandung senyawa yang terdiri dari kurkumin, minyak atsiri, lemak, karbohidrat, protein, vitamin $\mathrm{C}$, dan garam-garam mineral berupa besi, fosfor, dan kalsium. Kurkumin berfungsi sebagai antioksidan, anti inflamasi, dan berperan dalam perbaikan jaringan sel hati dan oviduk (Somchit et al. 2005).

Ravindar et al. (2007) menyatakan bahwa kunyit mengandung fitoestrogen yang memiliki kesamaan dengan estradiol, sehingga dapat merangsang hati untuk mensintesis vitelogenin. Kunyit akan memacu kinerja hati untuk metabolisme nutrien yang digunakan sebagai penyusun vitelogenin sehingga meningkatkan perkembangan folikel. Selain itu, kurkumin yang terkandung dalam kunyit berfungsi sebagai hepatoprotektor yaitu membantu proses perbaikan fungsi hati dengan cara mempercepat regenerasi sel hati dan melindungi hati dari pengaruh hepatotoksik yang dapat merusak hati (Somchit et al. 2005).

Oleh karena itu, penambahan bahan alami kunyit dalam pakan patut diuji coba pada ikan serukan untuk mengamati perubahan yang terjadi pada gonad dan performa reproduksinya. Penelitian ini bertujuan untuk mengevaluasi pertumbuhan dan perkembangan gonad ikan serukan yang diberikan pakan tepung kunyit.

\section{METODE PENELITIAN}

Penelitian dilaksanakan pada bulan Juni-September 2018 di Unit Pembenihan Rakyat (UPR) Kecamatan Beutong, Kabupaten Nagan Raya.

\section{Prosedur Penelitian}

Materi Uji

Materi uji yang digunakan adalah calon induk ikan serukan hasil tangkapan dan penangkaran kelompok petani ikan di Kabupaten Nagan Raya, Provinsi Aceh, sedangkan bahan uji adalah tepung kunyit.

\section{Pembuatan Pakan Uji}

Pakan yang digunakan adalah pelet komersil dengan kandungan protein 30-32\%. Penambahan tepung kunyit dilakukan dengan cara diaduk merata ke dalam pakan kemudian disemprotkan air sebanyak $20 \mathrm{ml} / \mathrm{kg}$ pakan. Selanjutnya pakan dikeringkan di tempat yang teduh dan terhindar dari cahaya matahari langsung. 
Rancangan Percobaan

Penelitian dirancang dengan metode eksperimental berupa rancangan acak kelompok (RAL) yaitu 4 perlakuan dan 3 kali ulangan. Tiga dosis tepung kunyit dicampur ke dalam pakan yaitu $0,2,0,4$, dan $0,6 \% / \mathrm{kg}$.

Pemeliharaan

Induk yang digunakan dalam percobaan adalah induk betina ikan serukan sebanyak 120 ekor (10 ekor/wadah) berukuran panjang 12-14 $\mathrm{cm}$ dan bobot 30-40 g hasil tangkapan dan penangkaran kelompok petani ikan di Kabupaten Nagan Raya. Wadah yang digunakan yaitu keramba jarring tancap ukuran 1 x 1 x 1 m sebnyak 12 unit.

Pemberian pakan secara restricted dengan feeding rate (FR) 3\% per hari dari biomassa frekuensi pemberian pakan sebanyak dua kali sehari, yaitu pada pagi hari pukul 08.00 WIB dan sore hari pukul 18.00 WIB.

\section{Parameter Uji}

Hepatosomatic Index (HSI)

Nilai HSI dihitung berdasarkan perbandingan antara bobot hati dengan bobot tubuh ikan. Pengamatan HSI dilakukan dua kali yaitu pada awal dan akhir penelitian. Nilai HSI dihitung dengan menggunakan rumus:

$$
\text { HSI }(\%)=\frac{\text { Bobot hati }(\mathrm{g})}{\text { Bobot tubuh }(\mathrm{g})} \times 100
$$

\section{Gonadosomatic Index (GSI)}

Nilai GSI dihitung berdasarkan perbandingan antara bobot gonad dengan bobot tubuh ikan. Pengamatan HSI dilakukan dua kali yaitu pada awal dan akhir penelitian. Nilai HSI dihitung dengan menggunakan rumus:

$$
\text { GSI }(\%)=\frac{\text { Bobot gonad }(\mathrm{g})}{\text { Bobot tubuh }(\mathrm{g})} \times 100
$$

Pertumbuhan

Pertumbuhan yang diamati yaitu penambahan bobot dan panjang dengan menggunakan rumus berikut:

$$
\mathrm{G}=\mathrm{Wt}-\mathrm{W} 0
$$

Keterangan:

G : Pertumbuhan bobot (g)

Wt : Bobot akhir pemeliharaan (g)

W0 : Bobot awal pemeliharaan $(\mathrm{g})$

$$
\mathrm{L}=1 \mathrm{t}-10
$$

Keterangan:

$$
\begin{array}{ll}
\mathrm{L} & : \text { Penambahan panjang }(\mathrm{cm}) \\
\mathrm{lt} & : \text { Panjang akhir pemeliharaan }(\mathrm{cm}) \\
10 & : \text { Panjang awal pemeliharaan }(\mathrm{cm})
\end{array}
$$

\section{Analisis Data}

Data penelitian ditabulasi dan dianalisis menggunakan program MS. Office Excel 2013 dan analisis sidik ragam ANOVA pada selang kepercayaan $95 \%$ menggunakan program SPSS versi 22.0, apabila berbeda nyata maka akan dilakukan uji lanjut Duncan. Khusus untuk data HSI dan GSI dianalisis secara deskriptif. 


\section{HASIL DAN PEMBAHASAN}

\section{Pertumbuhan}

Hasil pengamatan pertumbuhan disajikan pada Gambar 1 dan 2 yang menunjukkan bahwa penambahan bobot terbaik yaitu P2 (dosis 0,2\%) dengan penambahan sebesar 29,18 g, diikuti P4 (dosis $0,6 \%$ ) sebesar 28,57 g, P3 (dosis 0,4\%) sebesar 28,2 g dan P1 (kontrol) sebesar 26,45 g. Uji statistik menunjukkan bahwa adanya perbedaan yang nyata antar perlakuan $(\mathrm{P}<0,05)$. Sedangkan penambahan panjang terbaik yaitu $\mathrm{P} 2$ sebesar $2,87 \mathrm{~cm}$ diikuti $\mathrm{P} 1$ sebesar 2,48, P4 sebesar 2,47 dan P3 sebesar 2,41. Uji statistik menunjukkan bahwa adanya perbedaan yang nyata antar perlakuan $(\mathrm{P}<0,05)$.

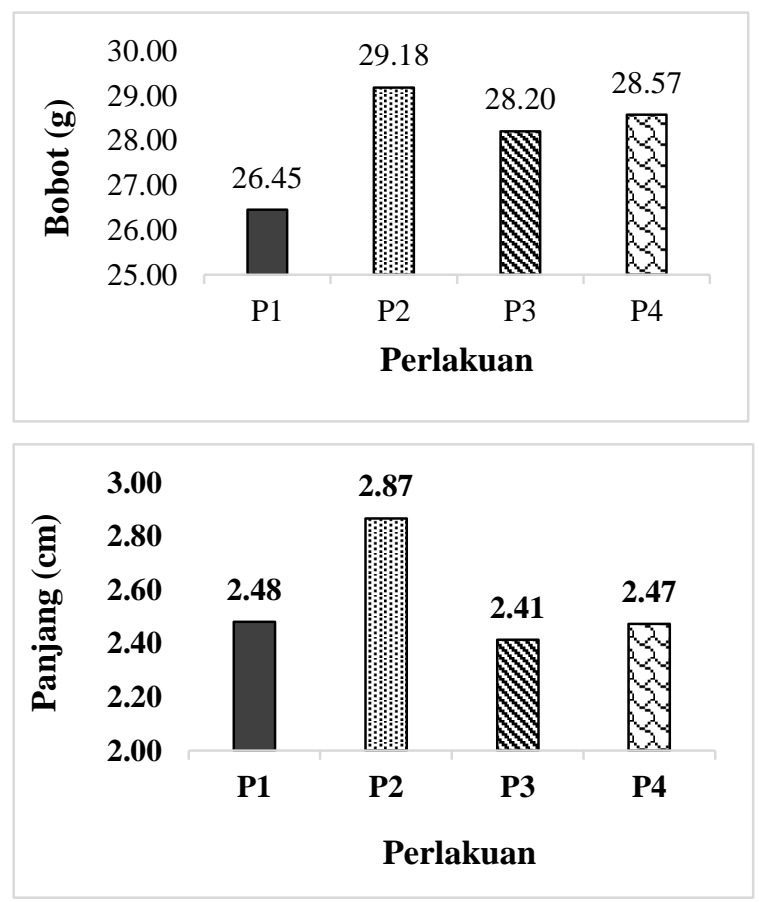

Pertumbuhan ikan dapat dipengaruhi oleh beberapa faktor diantaranya nutrisi, genetik/keturunan dan lingkungan. Jika dilihat dari faktor nutrisi, protein merupakan nutrient yang paling berperan namun hal-hal lainnya juga perlu diperhatikan dalam memproduksi pakan seperti pakan yang mudah dicerna dan disukai oleh ikan. Hasil penelitian menunjukkan bahwa penambahan tepung kunyit dalam pakan dapat meningkatkan pertumbuhan (bobot dan panjang) ikan serukan (Gambar 1 dan 2). Hal tersebut diduga karena kunyit dapat mempengaruhi nafsu makan dan tingkat kecernaan makanan oleh ikan meningkat. Meningkatnya nafsu makan dan tingkat kecernaan yang baik tentunya akan dapat meningkatkan pertumbuhan ikan karena nutrient yang ada dalam pakan diserap secara maksimal oleh ikan.

\section{Gonadosomatic index (GSI)}

Hasil pengamatan gonadosomatic index induk jantan dan betina disajikan pada gambar 3 dan 4. Hasil GSI induk jantan tertinggi yaitu P3 sebesar $11,28 \%$, diikuti P4 sebesar $8,63 \%$, P1 sebesar $6,9 \%$ dan P2 sebesar $6,46 \%$. Sedangkan GSI induk betina tertinggi yaitu $\mathrm{P} 4$ sebesar $15,24 \%$ diikuti P1 sebesar 12,56, P3 sebesar 12,22\% dan P2 sebesar $12,1 \%$.

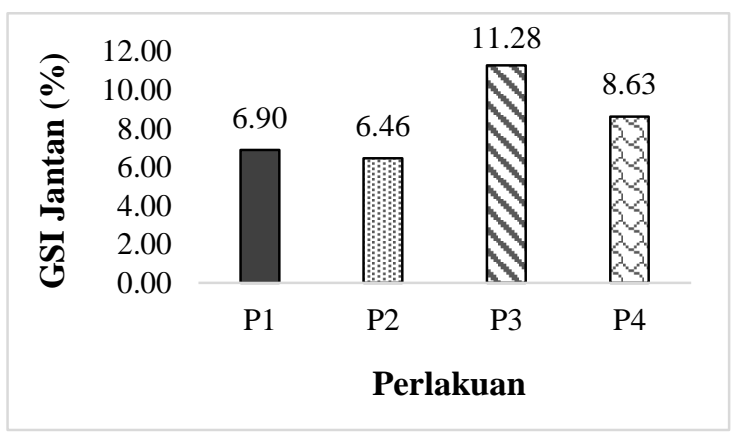

Gambar 3. Gonadosomatic index induk jantan ikan serukan

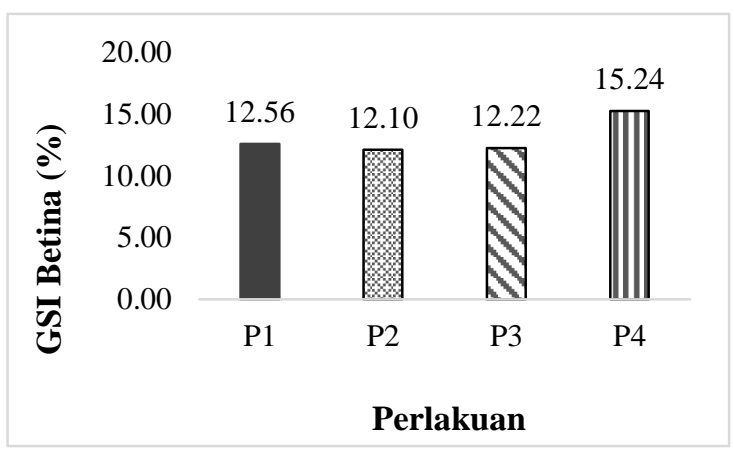

Gambar 4. Gonadosomatic index induk betina ikan serukan

Gonadosomatic index digukan sebagai parameter dalam menentukan tingkat kematangan gonad (TKG), GSI diukur 
berdasarkan perbandingan bobot tubuh dan berat gonad serta untuk memperkirakan waktu pemijahan ikan (Wootton \& Smith, 2014). Tingkat kematangan gonad sangat dipengaruhi oleh makanan dan lingkungan, pemberian makanan yang mengandung protein tinggi dapat mempercepat proses tersebut. Selain itu, penambahan zat atau nutrient lainnya juga mempengaruhi proses perkembangan gonad ikan, seperti pemberian kunyit yang dilakukan pada penelitian ini. Kunyit mengandung fitoestrogen yang memiliki kesamaan dengan estradiol sehingga dapat merangsang hati untuk memproduksi vitellogenin. Hasil penelitian menunjukkan bahwa penambahan tepung kunyit dalam pakan dapat meningkatkan nilai GSI baik pada jantan maupun betina. Hal tersebut menandakan kunyit dapat mempercepat proses pematangan gonad ikan serukan. Hasil serupa juga diterangkan dalam penelitian Sari (2015) bahwa pemberian tepung kunyit 0,25 $\mathrm{g} / \mathrm{kg}$ induk dapat mempercepat pematangan gonad dan performa reproduksi ikan lele sangkuriang (Clarias gariepinus).

\section{Hepatosomatic Index (HSI)}

Hasil pengamatan hepatosomatic index induk jantan dan betina disajikan pada gambar 5 dan 6. Hasil HSI induk jantan tertinggi yaitu P4 sebesar 1,29\% diikuti P3 sebesar 1,22\%, P2 sebesar $0,79 \%$ dan P1 sebesar $0,76 \%$. Sedangkan HIS induk betina tertinggi yaitu $\mathrm{P} 3$ sebesar $1,14 \%$ diikuti P4 dan P1 sebesar 0,95\% dan P2 sebesar 0,76\%.

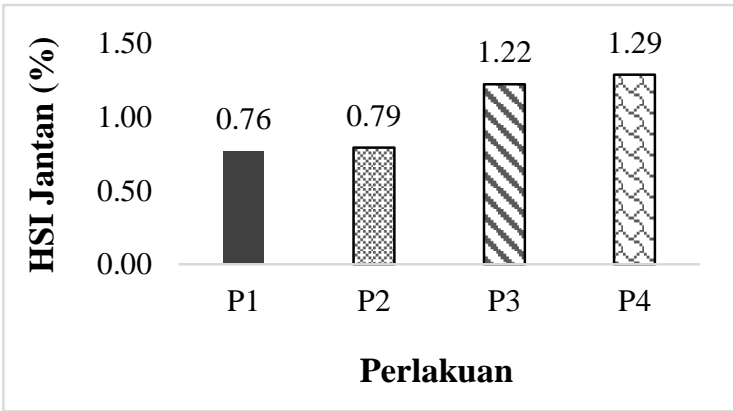

Gambar 5. Hepatosomatic index induk jantan ikan serukan

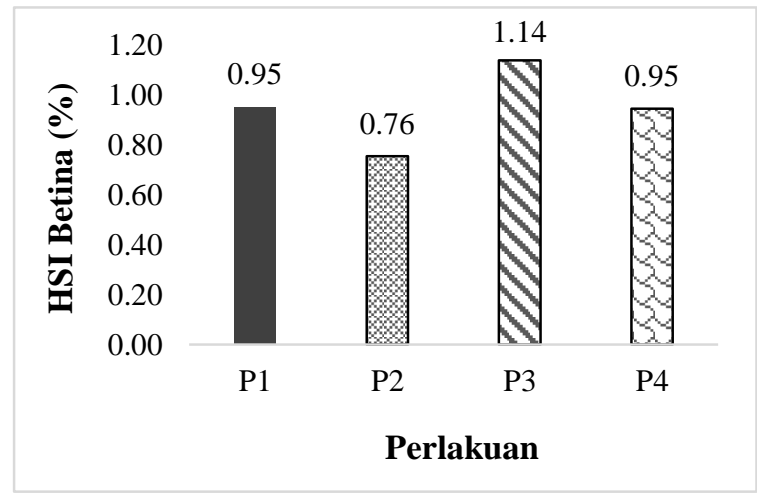

Gambar 6. Hepatosomatic index induk betina ikan serukan

Hepatosomatic index (HSI) juga merupakan salah satu parameter yang dapat menggambarkan tingkat atau fase perkembangan gonad ikan, karena hati merupakan tempat produksi vitelogenin sebagai bahan dasar pembentukan kuning telur atau disebut proses vitelogenesis dengan bantuan hormon 17ß-estradiol. Hasil penelitian menunjukkan bahwa penambahan tepung kunyit dalam pakan dapat meningkatkan nilai HSI induk ikan serukan baik pada induk jantan (Gambar 5) maupun betina (Gambar 6). Nilai HSI meningkat seiiring dengan proses vitelogenesis yang memacu hati bekerja lebih dari keadaan normalnya.

\section{KESIMPULAN}

Penambahan tepung kunyit dalam pakan dapat meningkatkan pertumbuhan dan mempercepat proses perkembangan gonad ikan serukan (Osteochilus sp). Dosis terbaik yaitu penambahan tepung kunyit sebanyak $0,6 \%$ per kg pakan.

\section{UCAPAN TERIMA KASIH}

Terima kasih disampaikan kepada Kementerian Riset, Teknologi dan Pendidikan Tinggi yang telah mendanai penelitian ini melalui skema Penelitian Dosen Pemula (PDP) tahun anggaran 2018. 


\section{DAFTAR PUSTAKA}

Arfah H, Melati, Setiawati M. 2013. Suplementasi vitamin E dengan dosis berbeda pada pakan terhadap kinerja reproduksi induk betina ikan komet (Carassius auratus auratus). Jurnal Akuakultur Indonesia. 12(1):14-18.

Dewi CD. 2015. Khasiat Tepung Kunyit (Curcuma longa) dalam Pakan Untuk Meningkatkan Performa Reproduksi Ikan Patin Siam (Pangasianodon hypophthalmus) [Tesis]. Bogor (ID): Institut Pertanian Bogor.

Itokawa $\mathrm{H}$, Shi $\mathrm{Q}$, Akiyama $\mathrm{T}$, MorrisNatschke SL, Lee K. 2008. Recent advances in the investigation of curcuminoids. Chinese Med 3:11.

Muchlisin ZA, Arfandi G, Adlim M, Fadli N, Sugianto. 2014. Induced spawning of seurukan fish, Osteochilus vittatus (Pisces: Cyprinidae) using ovaprim, oxytocin and chicken pituitary gland extracts. AACL Bioflux 7(5):412-418.

Muchlisin ZA, Siti Azizah MN. 2009. Diversity and distribution of freshwater fishes in Aceh Water, NorthernSumatra, Indonesia. International Journal of Zoological Research 5(2):62-79.

Myers PR, Espinosa CSP, Jones GS, Hammond, Dewey TA. 2014. The Animal Diversity Web (online). Accessed at http://animaldiversity.org.

Ravindar PN, Babu KN, Silverman K. 2007. Turmeric. The Genus Curcuma.CRC Press. London, New York.

\begin{tabular}{ccr} 
Riyadh M. 2008. & Uji & Aktivitas \\
Hepatoprotektor & Senyawa & Hasil \\
Biotransformasi & Kurkumin & oleh \\
Kapang Endofit & Rimpang & Kunyit \\
(Curcuma longa & Linn.). & [Hasil \\
Penelitian]. Bogor (ID): Sekolah Tinggi \\
\multicolumn{4}{l}{ Teknologi Industri dan Farmasi. }
\end{tabular}

Sari A. 2016. Pengaruh Pemberian Oodev dan Tepung Kunyit (Curcuma longa) Terhadap Performa reproduksi induk betina lele sangkuriang (Clarias gariepinus) [Skripsi]. Bogor (ID): Institut Pertanian Bogor.

Somchit MN, Zuraini A, Bustaman AA, Sulaiman MR, Noratunlina R. 2005. Protective Activity of Tumeric (Curcuma longa) in Paracetamol-
Induce atotoxity in Rats. International Journal of Pharmacology.

Syandri H, Azrita, Junaidi. 2015. Fecundity of Bonylip Barb (Osteochilus vittatus Cyprinidae) in Different Waters Habitats. International Journal of Fisheries and Aquatic Studies 2(4): 157-163.

Syandri H. 2004. The use of Osteochilus vittatus and Puntius javanicus asa an agen of biological in Maninjau Lake. Journal of Natur Indonesia 6(2):87-91.

Tarigan N. 2016. Percepatan Pematangan Gonad dan Peningkatan Kualitas Telur Ikan Nilem (Osteochilus hasellti, CV) melalui Penambahan Vitamin E dalam Pakan [Tesis]. Bogor (ID): Institut Pertanian Bogor.

Wouters R, Cesar M, Patrick L, Jorge C. 2001. Lipid composition and vitamin content of wild female litopenaeus vannamei in different stages of sexual maturation. J Aquculture. 198:307-323. 